\title{
MUSIC ORIENTATION AND MUSICALLY RESTRICTED
}

\section{Summary \\ Introduction}

Music orientation basically means the individual's general attitude towards music. This may be active or passive (hobby or no hobby) and positive or negative by nature. The musically restricted is a group of people to whom music has no meaning. Their musical orientation has become negative and it has stayed passive. This phenomenon has not been widely researched and it has been discovered after the year 2000. Only a couple of articles have been written about it before this one. Some small researches (Syrjäkosk,i 2005) have been done on the basis of case research. The phenomenon was first mentioned in 2000 (Juvonen, 2000) and it seems to be rather uncommon (2-4\% of people seem to belong to the group.)

\section{Aim of the Study}

To recognize the prevalence of the phenomenon and to find out the reasons which lead into its forming.

\section{Materials and Methods}

This research is based on the data collected in 2005 with the help of an internet questionnaire which was answered in 36 schools in different parts of Finland. The total number of respondents was 426 out of which there were 239 female and 186 male respondents.

The qualitative analysis was done using text-analysis, classification and categorizing. The quantitative analysis included simple per cent frequencies, the usual statistical key figures (mean, median, mode, stated division) and cross tabling with the background variables. In cross tabling the significance level was for the chi squire p-value was 0.05 .

\section{Results and Conclusions}

It was clearly shown that the music orientation begins forming in early childhood. The number and the emotional charge of musical memories and musical experiences in childhood seem to be in significant connection with the development of the musical restriction as well as the music orientation. Also the conceptions, values and example as well as the atmosphere at home are important factors in later music-relation of the child.

Key words: Musical orientation, general music orientation, specific music orientation, musically restricted.

\section{Introduction}

This article focuses on musical orientation (and its nature) including also the reverse phenomenon: musical restriction. Music orientation can be divided into general music(al) orientation and specific music(al) orientation. The general musical orientation may occur as positive or negative, and it may also be manifested active or passive. The activation process of general music orientation takes place when a person starts a musical hobby. If the orientation is basically negative, it will not enable the starting of the hobby, and the orientation will stay passive. Though, if the musical experiences get a strong positive impact it may lead into a change from negative orientation to a positive attitude and the orientation will change into positive direction. These changes may be 
rapid in childhood, but after they have become stable in the individuals personality (usually during the awkward age) the changes become slower from awkward age (Juvonen, 2000).

The definition of music orientation was developed in 2000 (Juvonen, 2000) and further research has been done since (Juvonen, 2004a; Juvonen, 2004b; Syrjäkoski, 2004). Musical restriction was theoretically introduced in 2000, but not empirically proved before the year 2004. The music restriction seems to be quite a rare phenomenon, only $2-4 \%$ of the population can be said to belong to the restricted group. The diagnosis of the syndrome (musical restriction) is not always easy, because people suffering from it are not often willing to tell about it. It is like illiteracy: one rather wants to keep it as a secret. People falling under the category of musically restricted often become very skilful in hiding the phenomenon; they often learn to act like they think normal people would act. In some cases they even try to learn the names of the groups or performers to be able to discuss them with their friends. In some cases there has occurred bullying in some developmental period which has worsened the situation for some individuals suffering from this syndrome (Syrjäkoski, 2004; Juvonen, 2005a, 2005b). In some cases the cause of the music restriction has shown to be a type of hypersensitiveness in the music area: for some people it is impossible to hear music without total concentration on it: incidental music, muzak or background music makes their life miserable. There also are cases in which individuals for example listen to sports commentaries instead of music to be able to relax (Sanomat, 2005).

\section{Aim of the Study}

To recognize the prevalence of the phenomenon and to find out the reasons which lead into its forming.

\section{Materials and Methods}

These reasons were researched from the early childhood experiences, the atmosphere at home and the attitudes of parents towards music generally. As we know a child adopts the values, conceptions and the behavioural models mostly from own parents in early childhood. This is also the most important time when the musical conceptions form. Most of the modern children cannot avoid hearing music almost all the time: kindergarten, mothers and siblings singing and playing musical instruments, media in common, especially radio and TV, but also internet offers a continuous possibility to hear music. Musical experiences on a personal level form the basis for building further musical orientation. Usually a child builds a positive orientation for music and singing, this is if the strongest and the most important experiences have a positive impact. However, the latest research has shown that there is a group of people to whom music has no meaning. They have not formed musical orientation in the traditional meaning and they feel outsiders concerning music and musical achievement. This phenomenon is quite rare and usually it is not found without a thorough investigation. This is because the phenomenon is considered as a handicap or a serious lack of ability or skills. We may compare it with illiteracy in a way because the included people are most willing to keep it in secrecy (Juvonen, 2000; Juvonen, 2005a; 2005b; Sanomat, 2005).

In a modern society being able to "read", interpret and understand different means and channels of information, different types of expressions as well as languages in all possible forms of transmission of thoughts is essential. The information society is built on these fundamental elements. If a person lacks one or several of these means, he cannot enjoy a balanced life inside the society: he becomes a drop-out in the very area he is missing. The lack of ability to communicate through different arts also takes away an important factor in life generally. The individual cannot enrich his life through arts in such a case. This is one of the reasons that make research of the phenomenon of musical restriction so important, every citizen of the society should be given equal possibilities 
for development and enjoying life in balance and harmony with himself. The responsibility is, of course, mostly for the parents, but also for the kindergarten and school teachers dealing with arts and other subjects important in early childhood time. This is why the phenomenon should thoroughly be investigated so that it could be prevented beforehand with right achievements at school and in kindergarten.

The research material collected in the questionnaire of this research consisted lots of questions about the childhood time of the respondents. Earliest musical memories, their emotional impact, the amounts of memories, the age when these memories took place, the situations in which the memories were connected to were thoroughly researched. The musical life at childhood home, kindergarten and at the beginning of the school were inquired with questions about general music achievement experiences, musical hobbies, the attitude towards music, concerts, and instrument playing as well as the parental attitudes and conceptions about music. The musical taste and the strength of musical experiences, the impact the music has for each individual and also the interests in different areas of musical achievements were asked from the respondents. The music hobbies, reason for beginning and ending one as well as the experiences from it were inquired. The meaning of music for an individual's personal life was one of the most important focuses in the research. It was explained through a series of questions. The questions were both structured and open-ended, and the open-ended questions were used both as qualitative material and quantitative material (after quantification). The qualitative analyzes were done using text-analyzing, classification and categorizing. The quantitative analyze included simple per cent frequencies, the usual statistical key figures (mean, median, mode, stated division) and cross tabling with the background variables. In cross tabling the significance level for the chi squire p-value was 0.05 .

The musically restricted and oriented were defined using a wide criteria consisting of the (open ended and structured) questions about: meaning of music in life generally, having music as a hobby, having clear targets in musical achievement, conceptions about one's own musical abilities and musicality. After the definition, the two groups were cross tabulated with the early childhood experiences and compared with each other to find out the significant factors distinguishing them from each other. The methods used in group definition were both qualitative and quantitative and the methods used in comparing the groups were mostly quantitative, but in some cases also qualitative data was used.

\section{Collecting the data}

This article is based on a large research made in 2005 (Anttila, Juvonen, 2006). The data was collected through an internet questionnaire which was sent to several hundreds of Finnish upper level of comprehensive schools ( $8^{\text {th }}$ class) and upper secondary schools ( $1^{\text {st }}$ class). Some of the schools did the answering during their music lessons and some teachers just gave the email address of the questionnaire to their pupils so that they could answer from their own computers. The data consisted of 426 answers from 36 different schools all around Finland (see Picture 1).

There were 239 female and 186 male pupils answering the questionnaire, and the age deviation was between 14 an 18 years mean being 14.8 (std. dev. 1.002) and the mode 14

Picture 1. The answerer's domiciles.

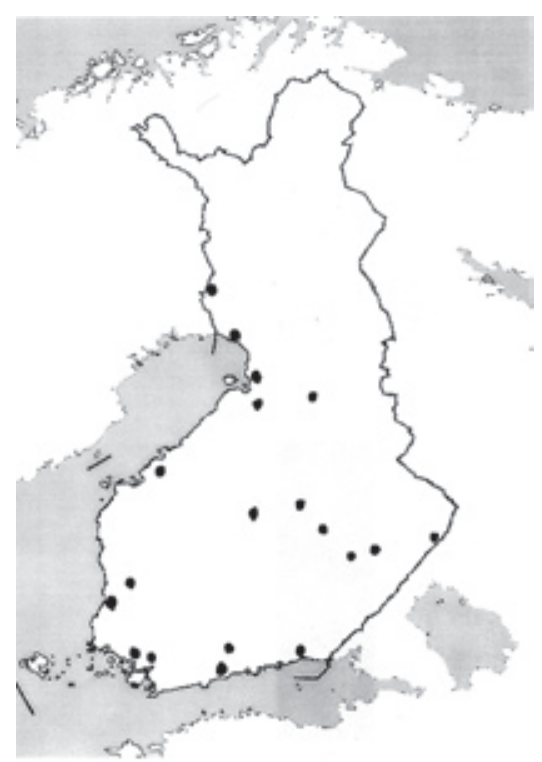


years. $23.5 \%$ of the answerers came from the $1^{\text {st }}$ class of the upper secondary school and $76.5 \%$ from $8^{\text {th }}$ class of the upper comprehensive school. The questionnaire consisted of structured questions and open ended questions focusing in the music orientation and music learning motivation widely. In this article I only focus in music restriction through musical orientation questions.

\section{Music enculturation}

As it has been many times shown, music is a difficult phenomenon to definite. Many musicologists and music philosophers have been trying to definite it through the decades. Often it is defined as a humanly produced and remoulded sound, but still this definition is not complete. For example a tickle of a clock is humanly produced sound but it is not music. Music is surrounding us in a modern society every day and almost everywhere, and therefore it is difficult to ignore the phenomenon. Music may have many different meanings depending on the purpose it is made: it may be serious art, entertainment, or even the most important thing in one's life. It may be therapeutic, it may have sexual impact, it may have propagandist or political and even religious aims. Also the new technology has brought new views in front of us all in matters of reproduction and distribution of music. When a hundred years ago the main source of music was a live person playing a musical instrument or singing, the whole situation has completely changed today. Music has become very important factor in lives of young people of today. It is often a mark of style and it easily shows the peer group of youngsters.

Music is one of the elements which a child adopts in his social development process during the first years of life. This process may be called socialization, enculturation or even acculturation (when it takes place in an unfamiliar culture) in research literature. The process is directly connected to hearing processes: the child hears the music which is typical to the society surrounding him. (This enculturation process can be in some extend compared to learning of the mother tongue.) The hearing of music is not only dependent to the music the parents are willing to play or sing to a child, music comes from many sources which are not controlled by parents of a child. These are radio, television, internet, portable telephones, computer games and other media. During this enculturation process we all learn and adopt the musical laws and typical scales which are mostly used in the music surrounding us. This so called "western" music tradition consists of many music styles which a child hears during the socialisation processes. Some research has been done about the musical surroundings of a child in a modern society (Helkimo, 2004; Taskinen, Ylinen, 2005; Pesanto, 2005). The research has shown that in Finland a child hears mostly Finnish pop-rock music, next comes international pop music and after that children's songs and classic music. A child only hears classic music $7-10 \%$ of all the music surrounding him in childhood before the school beginning. It is also shown that in modern society only few (4.1\%) Finnish mothers are singing lullabies to their children (Helkimo, 2004). These facts are in direct connection with the music education at schools but this will not be discussed in this article any further.

All these mentioned first musical experiences are very important to the development of the general musical orientation of a child. The growing child constructs his own music conceptions thought the music he hears, sees and experiences he gathers from early childhood. The impact of the experiences is strong especially in field of feelings and emotions and the music experiences are connected closely in these emotional charges. The nuances of these experiences may even reverberate to adult age music orientation. Home is the most important source of all early childhood experiences also in music area. The atmosphere at home towards music and musical phenomenon forms the basics for the general music orientation developing in early age.

A child starts hearing music already before it is born. He hears the sounds from outside, but 
also the sounds of the mother's body: different rhythms of breathing, the sound of the mother's heart beating in different tempos and also the sounds of speech. This starts the enculturation process to music.

Slowly the musical experiences start to form a model in the mind of a child. He starts to understand why music exists, what is the meaning of different music styles and he starts to notice when the music is made correctly and when it is not done correctly. The idea of music in the society a child is living in slowly starts to become clear in the growing mind. The connections between different musical events start to become significant in a child's life. Some musical events get a positive charge and some others get a negative charge. Negative charge may be caused by surprise, too loud volume or some unpleasant accident while hearing the music. It may also be caused by negative attitude of adults considering music, singing or performing music.

It may also happen that a child does not get many musical experiences in early childhood though it is quite unusual because of the technical development which has brought music all around us almost all the time. In this kind of situation the general musical orientation cannot develop in a child's mind. This may lead to musical restrictions later (Juvonen, 2000).

Musical enculturation process is directly connected to the whole socialisation process where the child adopts all the norms and habits of the surrounding culture. Only a small part of the learning processes during this time are done purposefully, most of them are done subconsciously. In the early years the individuality of a child is not especially emphasized in music matters because the society offers the typical music events for the child. The musical taste and individuality in music relation develops later in the awkward age when a child starts to form the identity and rebel against his parents. It is often through the music that the mutiny is shown.

\section{General and specific music orientation}

General musical orientation consists of musical self conception, musical competence and music conceptions which most often show out as the musical taste. Musical self conception basically is built on the experiences in childhood. It may be positive, neutral or even negative. When music self conception is negative, it effectively inhibits the musical orientation to evolve. It is because the negative musical self conception makes a person to avoid all musical activity which also makes the music competence restrain in low level. It also has direct connections to musical self confidence and musical self conception.

Musical competence can develop only through musical achievement, singing, moving with the music and through learning to play musical instruments. The development of the competence is quite dependent of positive feedback when trying out the music instrument playing first times. If the experiences are humiliating or embarrassing, it may have bad consequences later in field of music orientation. This kind of experiences even may lead to musical restrictedness in worst case.

Music conceptions may be divided in three main lines (Karttunen, 2002). They are hierarchic, cultural and autonomic music conceptions. In hierarchic music conception the musical styles and genres are put in a hierarchic order in which the highest represents the best and the most valuable music. This is often seen in the field of classical music, but sometimes also among punk or heavy music enthusiasts (Juvonen, 2000). The autonomic music conception sees all music styles as autonomic with their own rules and laws which makes the comparison between the styles impossible. The third music conception is built on a thought that one can understand music only through understanding the culture where the music style comes from. Usually the music conception of a man is a mixture of these three basic types. The music conception forms the basics of the whole music relationship and orientation of a person (Karttunen, 2002). 
General music orientation may be active or passive. When a person starts instrument playing the orientation becomes activated. This may only happen when the general orientation is positive by nature. When instrument playing is started, the musical competence starts developing which also effects in musical self conception and musical taste. In good circumstances this may lead into the development of a specific musical orientation. (The development of general and specific musical orientations is described on the picture 2).

Picture 2. The forming of general music orientation and specific music orientation.

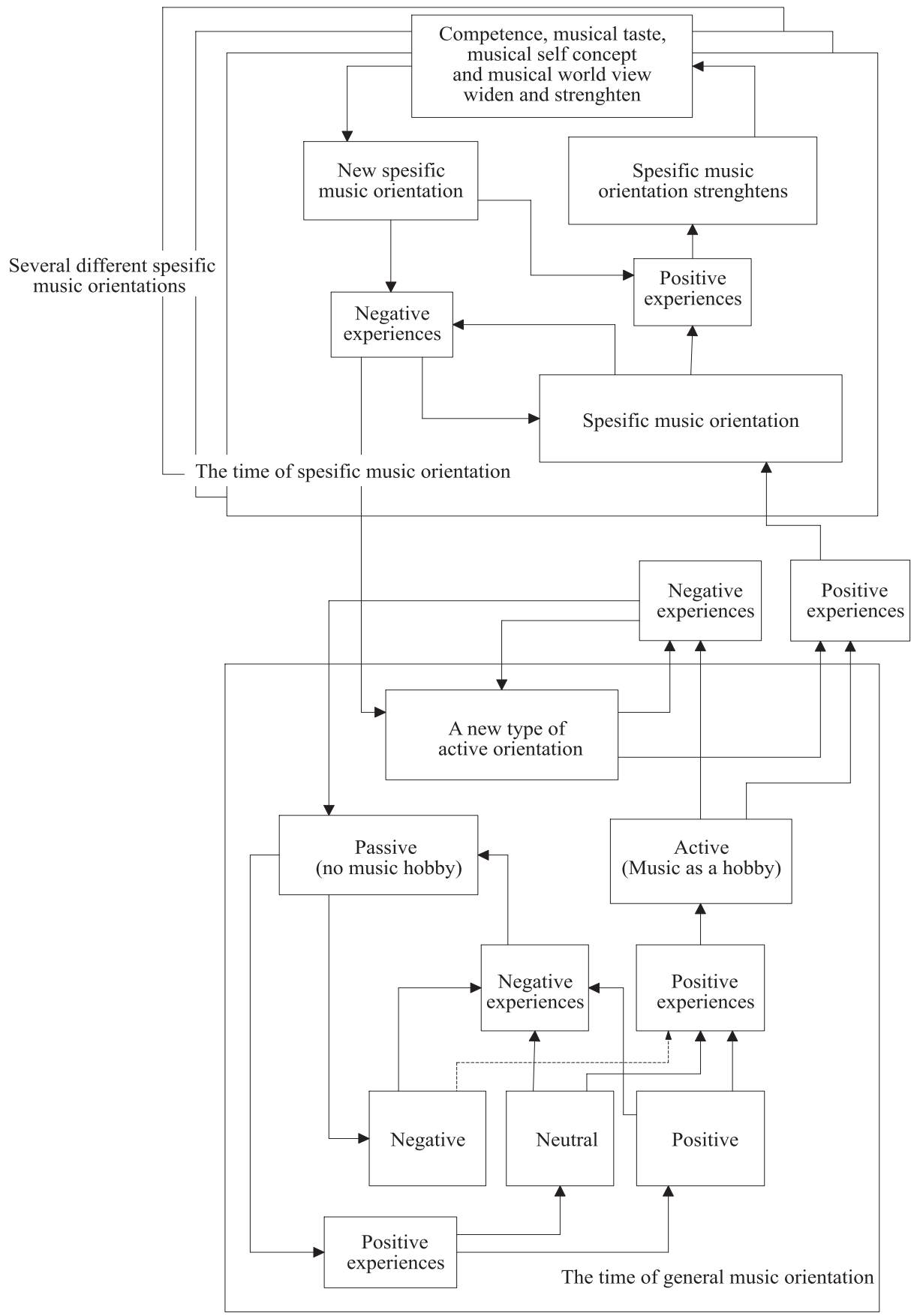


The positive experiences in the time of general music orientation development are especially important. If the experiences are negative, the general music orientation will stay negative by nature, and the activation of the orientation is not possible. When there are positive experiences the general music orientation starts to change to positive direction which makes the activation possible. When the general music orientation is activated to the level of musical hobby, it starts building musical competence which will lead to stronger musical self conception. It also widens the music conception and gives new inspiration to development of musical taste. Slowly the general music orientation may develop to a specific music orientation: music gets more and more meaning in the life of the person. In many cases this specific musical orientation leads to the point when music becomes the most important thing in life of the person. At that point the musical self conception may be the most important part of individual's personality.

The specific musical orientation may concentrate in different qualities of the musical achievement. There are always some of the following factors present in the specific musical orientation.

1) Instrument or a whole group of instruments;

2) Music style or genre;

3) Musical form (opera, chamber music etc.);

4) Performance style or social situation of music performance (choir, hobbyist group etc.);

5) The message of the music (religious music, punk, heavy etc.);

6) The usage of the music (rap, music as a background of dancing hobby);

7) Ceremonial music (Church music, military music);

8) Economical interests behind the music making;

9) General interest in music as a means for wellbeing.

\section{Results}

There were 24 answerers (16 female and 8 male) in the whole group who had a specific musical orientation (5.6\%). Music was the most important thing in their life and they spent many hours for their musical hobby every day. On the other hand, there were 14 persons in the group who could be called musically restricted. All of them were boys. These were the respondents who considered that music does not raise any feelings or emotions in them and music has no meaning in their life. They did not want to listen to music or have anything to do with it. The rest of the respondents in the group (91.1\%) had a normal active or passive general musical orientation, many of them had music as a hobby, they listened to music every day and music had a positive meaning in their life although it was not the most important thing they also had many other hobbies besides listening to music or playing an instrument.

Persons with specific musical orientation had a lot of musical memories from their childhood, and musically restricted had only a few of them. The difference between the groups was strongly statistically significant $(\mathrm{p}=0,000)$. Also the emotional charge of the memories was different within the groups: musically restricted had negative memories connected to music and music making from their childhood. They had been humiliated and laughed at when they had been singing or playing musical instruments. In many cases the memories were related to school. This means that musically restricted did not have many situations at home for listening to music or singing that is why their musical memories from early childhood were scarce.

The group of specific musical orientation had a lot of positive memories from early childhood before time of school beginning. Their memories also were situated in much earlier age than those of the other group. They often had music as a hobby at their homes (parents, sisters and brothers 
playing an instrument), a lot of singing also took place in their homes $(\mathrm{p}=0,000)$ while musically restricted homes had a negative attitude against the music as a whole. Also their (musically restricted group) musical memories were situated in older age than the other group.

Those with a specific music orientation considered music as a very effective emotional factor. The difference from the musically restricted group was statistically significant $(\mathrm{p}=0,000)$, which means that the respondents with specific music orientation gave music much more meaning in their minds and emotions than the other group. This can be connected to the lack of musical experiences of the restricted group in their childhood. Those with a specific music orientation had been singing in a choir clearly much more often than the other group.

The musical self conception of the specific music orientation group was significantly more positive than that of the other group $(\mathrm{p}=0,000)$. The members of the specific orientation group considered themselves as musically talented on the contrary to the other group, who thought to be non-musically talented.

The musically restricted group consisted only of male answerers, and they came from different parts of Finland. They focused their hobbies in nature sports, fishing and backpacking. There can be seen a clear connection traced to the negative musical experiences in childhood with the restriction in musical area. This group did not have a possibility to develop their general musical orientation in early childhood in a positive way, and their earliest musical experiences took place at school. They considered themselves as not musically gifted and they did not give music any meanings in their life. Music had no emotional or other connections in their minds and they did not like the music lessons at school. Musically restricted considered the whole music education at school to be meaningless and insignificant to their life.

\section{Conclusions}

The childhood experiences are closely connected to musical orientation and its development. The attitude towards music, singing and music making with instruments at home are very important. If the parents have a neutral or negative attitude to music, it is possible that the general musical orientation of the child will be disturbed or develop in a negative way. The early childhood experiences guide the musical self-conception into positive or negative direction, and they also are connected to the musical competence which starts to build together with musical experiences. At the same time the music conceptions are adapted through the enculturation and socialisation processes. These processes offer a great challenge to all parents and kindergarten teachers as well as preschool and elementary school teachers.

The kindergarten, preschool and school music education should be planned to support all the pupils: both the musically talented as well as the less talented. The music may be a source of joy for all pupils and it should be taught in a way which offers everyone a possibility to learn and enjoy music in their lives. The musically restricted (3-4\%) should be given a possibility to build their music orientation in a safe atmosphere where they would not be humiliated in any way. Their childhood situations have in many cases been musically unfavourable, but the situation can be corrected during the school time if the teacher has enough knowledge and patience and the emotional atmosphere at the classroom is positive. 


\section{REFERENCES}

1. Anttila M., Juvonen A. (2006) Musiikki koulussa ja nuoren elämässä. Kohti kolmannen vuosituhannen musiikkikasvatusta 3. Joensuu: Joensuu University Press. (Music at School and in Young Pupil's Life. Towards the Music Education of the Third Millennium, part 3. In Finnish.) 338 p.

2. Helkimo A. 2004. Alle kouluikäisten lasten musiikillinen ympäristö. Pro Gradu-työ. Julkaisematon. Joensuun yliopisto, Soveltavan kasvatustieteen laitos. (Under School Aged Children's Musical Surroundings). In Finnish. 102 p.

3. Sanomat H. (2005) Artikkeli Musiikkirajoitteiset. Nyt-viikkoliite 07.02.-13.02.2005. Ala-Korpela. Sivut 14-15). (Article Musically restricted in Helsingin Sanomat Weekly Edition 07.02.-13.02.2005. In Finnish.) p. $14-15$.

4. Juvonen A. (2000) ...Johnnyllakin on univormu, heimovaatteet ja -kampaus...: musiikillisen erityisorientaation polku musiikkiminän, maailmankuvan ja musiikkimaun heijastamina. (Also Johnny has a Uniform and a Hairdo... - Musical Self, Musical Worldview and Musical Taste as a Basic for Music Orientation.) Jyväskylä: Jyväskylä Studies in the Arts No 0. (In Finnish). 391 p.

5. Juvonen A. (2004a) The Changes in Music Declare Changes in Music Education System - There is a Lack of Music Education, but too many Music Educators - what's the Problem in Finland? Artikkeli teoksessa: $10^{\text {th }}$ Anniversary of RTTEMA. Coming 2004. Riga, Latvia. p. 41-48.

6. Juvonen A. (2004b) Kohti uutta paradigmaa: Musiikkikasvatus etääntyy esteettisistä lähtökohdistaan. (Towards a New Paradigm in Music Education - Music Education is Becoming Estranged to its Aesthetic Basics.) (Artikkeli Jorma Enkenbergin ja Maj-Britt Kentzin toimittamassa juhlakirjassa Marja-Liisa Julkuselle: Kasvatuksen maisemista.) Sivut 59-76. Joensuun Yliopisto Soveltavan kasvatustieteen laitos. In Finnish, p. 59-76.

7. Juvonen A. (2005a) Unpublished Research: Music Learning Motivation and Orientation at School. 50 p.

8. Juvonen A. (2005b) Unpublished Research: Music Learning Motivation and Orientation of the Classroom Teacher Students in Finland. Being printed. In Finnish, 165 p.

9. Juvonen A., Lasauskiene J. (2007) Musical Surroundings of a Child in Lithuania and in Finland. Article in Problems in Music Pedagogy (Davidova ed.) University of Daugavpils, Lithuania. p. 55-68.

10. Karttunen S. (1992) Musiikki kulttuurisessa tietoisuudessa. Jyväskylän yliopisto, Nyky-kulttuurin tutkimusyksikkö. Jyväskylä. (Music in Cultural Consciousness). In Finnish, 174 p.

11. Syrjäkoski M. (2004) “...Rockhenkilö ...vastoin parempaa tietoa...” Tapaustutkimus musiikkirajoittei suudesta, ilmiön luonteesta, synnystä ja vaikutuksista yksilön elämään. (Rock Person without a Better Knowledge... (A Case Study about Musical Restrictedness: the Nature of the Phenomenon, Birth of the Phenomenon and Effects to Life.) Joensuu: Joensuun yliopisto. In Finnish, 97 p.

12. Taskinen S., Ylinen H. K. (2005) Musiikki yhteistä on! Näkymiä suomalaisten ja liettualaisten lasten musiikillisista kotiympäristöistä. Pro Gradu-työ. Julkaisematon. Joensuun yliopisto, Soveltavan kasvatustieteen laitos. (Music is Common. Visions about Finnish and Lithuanian Children's Musical Surroundings at Home). In Finnish, $121 \mathrm{p}$.

13. Pesanto K. (2005) Ensimmäisen luokan oppilaan musiikillinen ympäristö. Pro gradu työ. Julkaisematon. Joensuun yliopisto, Soveltavan kasvatustieteen laitos. (First Class Pupil's Musical Surroundings). In Finnish, 103 p.

Senior Lecturer of Music Education, Docent Ph. D. Antti Juvonen

University of Joensuu

Address: Toonika-house, P.O. Box 111 (Tulliportinkatu 1), Fi-80101 University of Joensuu, Finland

Phone: +358 405830544

E-mail: antti.juvonen@joensuu.fi 